\title{
Studies on Regenerating Adrenal Cortex 2. Autoradiographic and Electron Microscopic Observations
}

\author{
MASATOSHI SEKI, SHIGETAKA SEKIYAMA, \\ HIROKO MIYAHARA AND SHOGO ICHII \\ Division of Physiology and Pathology, \\ National Institute of Radiological Sciences, Chiba
}

\begin{abstract}
Synopsis
Process of adrenocortical regeneration after bilateral enucleation was studied morphologically by histological autoradiography and electron microscopy. Results of the autoradiographical study revealed that adrenal enucleation induced a rapid cellular proliferation which was almost completed 20 days after operation. The present autoradiographical findings were in agreement with our previous biochemical results. Changes in size and shape of mitochondria and in mitochondrial cristae in addition to the development of network of smooth-surfaced endoplasmic reticulum were examined during the course of adrenal regeneration electron microscopically. The following morphological manifestation of mitochondrial structure, i.e. a) oval shape, b) enlargement in size, c) vesicular cristae and d) increase in so-called division (or septile structure) of mitochondria, seemed to be closely related to the steroidgenesis of the adrenal gland, as well as the development of the network of smooth-surfaced endoplasmic reticulum.
\end{abstract}

In a previous work (Ichii et al., 1968), process of the rat adrenocortical regeneration after bilateral enucleation was analyzed biochemically by examining the rate of incorporation of labeled nucleic acid precursors, together with DNA and RNA determinations and it was concluded that adrenal enucleation induced a rapid cellular proliferation which was almost completed 20 days after operation. Quantitative changes in the level of plasma corticosterone and in adrenocortical components, especially enzymes, which are considered to be related to corticosterone biosynthesis, were also investigated during the course of adrenocortical regeneration. As a clew to analyze the functional significance of the morphological changes of the cortical cells, the process of adrenocortical regeneration after bilateral enucleation was examined by histological autoradiography and electron microscopy. The results obtained will be described in the following.

Received for publication April 31, 1969.

\section{Materials and Methods}

\section{Animals}

Male rats of the Wistar strain, weighing 200 to $300 \mathrm{~g}$, were used. Conditions under which the experimental animals were maintained and the technique used for adrenal enucleation were the same as described in the previous report (Ichii et al., 1968).

\section{Histological Autoradiography}

${ }^{3} \mathrm{H}$-thymidine $(1.0 \mu \mathrm{C} / \mathrm{g}$ body weight $)$ was administered intraperitoneally on the 5th, 10th and 20th day after enucleation and the animals were sacrificed 1.5 hours after the injection. Intact animals, treated in the same manner, served as control. Adrenal glands removed were sliced about $1 \mathrm{~mm}$ in thickness, fixed in $2.5 \%$ glutar aldehyde and then embedded in Epon according to the usual electron microscopic technique. Sections, $2 \mu$ in thickness, were sticked on slide glass and autoradiographic specimens were prepared by the dipping method. Emulsion used was Sakura NRH-1 (Sakura Ltd. Co.) and exposure period was 4 weeks at $4^{\circ} \mathrm{C}$. They were developed with Konidol X (Sakura Ltd. Co.) for 6 minutes at $20^{\circ} \mathrm{C}$ and then stained with Giemsa solution. Cells which revealed two or more grains on the nucleus were referred to labeled cells, since silver grains of back ground were approximately 
$1 / 8 \times 10^{3} \mu^{2}$. Number of mitosis and labeled cells were counted per 1,000 parenchymal cells. The number of silver grain of each labeled cell was also counted.

\section{Electron Microscopy}

Tissues were fixed by Millonig's fixative (Millonig, 1962) for $2 \mathrm{hrs}$. at $4^{\circ} \mathrm{C}$ and embedded in Epon 812 . Ultra-thin sections were stained with uranyl acetate and lead hydroxide, and then observed under the JEM T-7 type electron microscope.

For a trial to obtain the detailed information on the changes of oraganella, the statistical examination was employed. Before trimming, each block was sectioned $2 \mu$ in thickness, stained by Giemsa solution and then examined light microscopically. The middle portion of zona fasciculata and of regenerating adrenal cortex was selected, and ultra-thin sections were prepared from this portion for the comparative study. It is well-known that zona fasciculata is composed of two cell types, i.e. light and dark cell (Lever, 1956; Nishikawa et al., 1963). However, the proliferating cells after enucleation were mainly light cells. For the statistical examination, therefore, the regenerating adrenocortical cells were compared with the light cells of intact control animals. The major axis of 500 mitochondria (386 in the case of the 20th day), which revealed obvious double membrane structure, was measured in each experimental group and was compared with those of the control. Other morphological characteristics were also examined in 500 mitochondria, which were selected at random in each group.

\section{Results}

\section{Autoradiographic Study}

The mitosis of control adrenal cortex was localized at the intermediate zone and the rate of mitosis was $0.6 \%$ of parenchymal cells. Incorporation of ${ }^{3} \mathrm{H}$-thymidine was also limited in the same zone and the rate of labeled cells was $0.8 \%$ of the parenchymal cells (Fig. 4 ). The number of grain in each labeled cell was less than ten.

Regeneration of cortical cells proceeded moderately at the 5 th day after enucleation. Parenchymal cells were piled up, forming a thin layer beneath the capsule and surrounding the centrically located hemorrhagic necrosis. Scar was formed between the parenchymal cells and necrotic mass (Fig. 5). Mitotic cells were observed within a few cell layer of subcapsular region and also at the cells adjacent to scar. The rate of mitosis was $5.4 \%$ of parenchymal cells. About $11.8 \%$ of parenchymal cells were labeled and grain number of each cell was much greater than those of the control (Fig. 6 and 7). Approximately $70 \%$ of the labeled cells contained more than 11 grains and $0.6 \%$ showed more than 40 grains (Fig. 1). Fibroblasts in the capsule revealed also remarkable labeling (Fig. 6).

At the 10th day after enucleation, cortical cells showed a cord-like arrangement, which was composed of $30-40$ of parenchymal cells at the subcapsular region (Fig. 8). Mitotic figure was located at the 4 th -5 th layers and the rate of mitosis was $0.5 \%$ of parenchymal cells. Incorporation of ${ }^{3} \mathrm{H}$-thymidine was observed in the same region of the tissue and the rate of labeling was $3.2 \%$ of the parenchymal cells (Fig. 9). Among the labeled cells, approximately $60 \%$ of cells contained $11-40$ grains, although the highly labeled cells more than 40 grains, were neglected.

At the 20th day after enucleation, cortical cells showed an obvious cord-like arrangement, and these arrangement resembled that of zona fasciculata of control adrenal (Fig. 10). At the subcapsular region, however, the arrangement of the cells was irregular or confused. Mitotic rate was $0.2 \%$ and labeled cells were $0.8 \%$ of parenchymal cells. Grain number per a labeled cell was less than 10 (Fig. 11).

\section{Electron Microscopic Study}

Ultrastructural observations were focused to the mitochondria and the network of smoothsurfaced endoplasmic reticulum, since morphological changes of these oragenelles may closely related to the biosynthetic function of corticosterone.

\section{1) Mitochondria}

In general, mitochondria of zona fasciculata of the control rats were round or oval in shape 

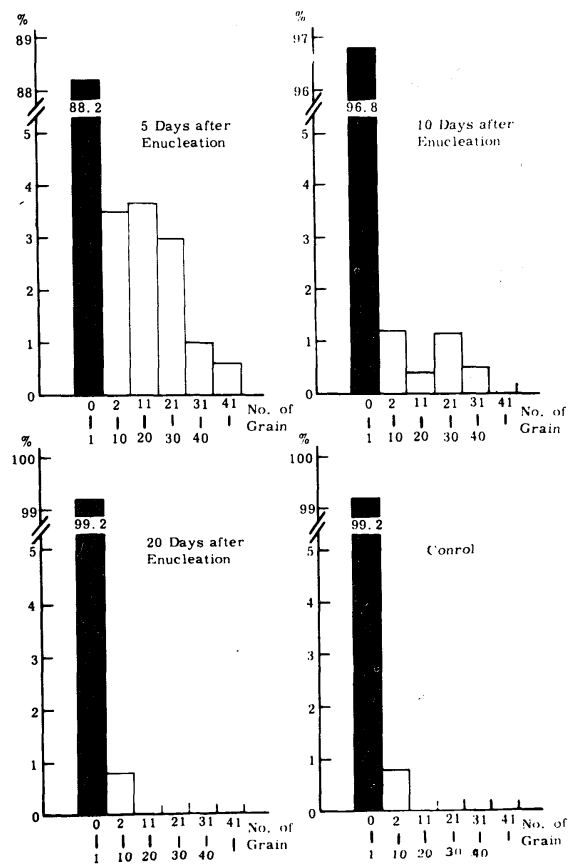

Fig. 1. Percentage of labeled adrenocortical cells after administration of ${ }^{3} \mathrm{H}$-thymidine. Black column shows percentage of negative cells which have no or one grain on their nuclei. Five days after enucleation, both of labeling index and grain number reveal remarkable increase.

and their size was widely distributed in the range from 0.5 to $4.6 \mu$, having a peak at $0.9-1.2 \mu$. Mitochondrial cristae were revealed to be vesicular or tubulo-vesicular profiles and the diameter of vesicular cristae was $600-$ $700 \mathrm{~A}$. Incidence of mitochondria which contained the tubular cristae, mixing with the usual vesicular or tubulo-vesicular ones, was $11.2 \%$ and that of microtubular cristae (Fig. 14) was $7.4 \%$. The latter type of cristae has been reported by Giacomelli et al., (1965) in zona glomerulosa cells. So-called division (or septile structure) of mitochondria (Fig. 12) and multilamination (De Robertis and Sabatini, 1958) were observed at the rate of $2.2 \%$ and $1.2 \%$ of examined mitochondria, respectively. Division of mitochondria was found only in the light cell, but multilamination was presented in both the light and dark cells (Fig. 13).

At the 5th day after enucleation, mitochondria was mainly small in size and round or oval in shape (Fig. 15 and 17), although elongated mitochondria, as shown in Figure 16, were sometimes observed. Concerning the distribution of mitochondrial size, which is indicated in Figure 2, large mitochondria of more than $2 \mu$ in the maximal diameter belong to such elongated mitochondria in the 5th and 10 th day cases. In the other cases, however, large mitochondria belong to oval-shaped giant type, which contain vesicular cristae. Almost a half of the mitochondria of the 5th day contained the cristae of tubular profils, mixing with usual tubulo-vesicular and or vesicular ones. So-called division of mitochondria and multilamination were scarcely observed at the 5 th day of regeneration.

At the 10th day after enucleation, the shape and the size of mitochondria were almost the same as those of the 5th day, and a few elongated mitochondria were still recognizable (Fig. 18). Mitochondrial cristae revealed tubulovesicular and vesicular profils, and the incidence of mitochondria, which contained the cristae of tubular profils, was lowered to $27.8 \%$. Division of mitochondria and multilamination were rarely observed.

At the 20th day after the enucleation, mitochondria in the regenerating cortical cells was enlarged, many of which have the maximal diameter in range of $1.3-1.4 \mu$. Giant mitochondria, as observed in control, were frequently encountered at this stage of regeneration (Fig. 19). Mitochondria showed the irregular shape and, sometimes, formed invagination to the adjacent mitochondria (Fig. 21). Mitochondrial cristae were mainly vesicular in profils as same as control. The incidence of mitochondria, which contained the cristae of tubular profils, was only $7.4 \%$. As shown in Figure 20, mitochondria with decreased number of vesicular cristae were often visible. Rate of division of mitochondria and multilamination were $1.2 \%$ and $3.2 \%$ respectively, as far as examined. 


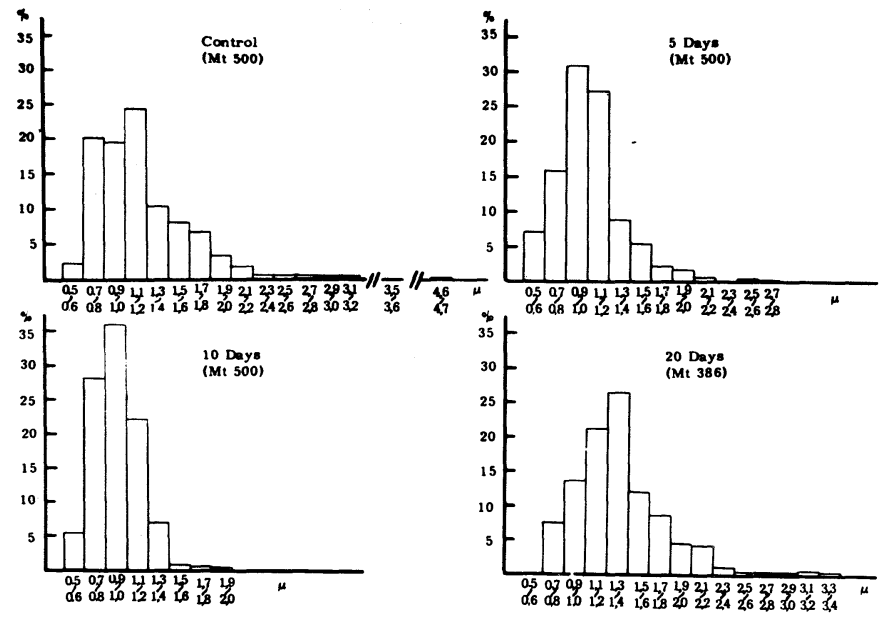

Fig. 2. Column shows the percentage of mitochondria which have the maximal diameter indicated under $x$-axis. In control animals, size of mitochondria is widely distributed from 0.5 to $4.6 \mu$. In 5 and 10 days cases, many of mitochondria are small in size and a few large mitochondria of more than $2 \mu$ belong to the elongated type. At the 20th day after enucleation, large mitochondria increase again. They belong to oval-shaped giant type as same as control.

\section{2) Endoplasmic Reticulum}

It is well-known that adrenocortical cells have large vesicles (about $300 \mathrm{~m} \mu$ ) and characteristic networks of the smooth-surfaced endoplasmic reticulum, but the typical roughsurfaced endoplasmic reticulum has not been observed (Ross et al., 1958). The facts were confirmed by the present observations, too. Large vesicles were distributed throughout the cytoplasm. They were not always round in shape, but frequently, especially neighbored to mitochondria, revealed flattened profils. Networks of the smooth-surfaced endoplasmic reticulum was only observed in the light cells, but not in the dark cells of control adrenals.

On the 5th day after enucleation, vesicles were predominantly found in the regenerating cortical cells and the network formation of the smooth-surfaced endoplasmic reticulum was rarely recognizable (Fig. 16 and 17). However, the network of endoplasmic reticulum was more frequently encountered on the 10th day and almost always observed at the 20th day in regenerated cortical cells. Table 1 indicates the development of the networking endoplasmic reticulum, as well as the changes of mitochondria and plasma corticosterone level.

\section{3) Other Organelles}

Star-like irregularly shaped lipid droplets were observed in regenerating adrenocortical cells on the 5th and 10th day after operation, and a small number of oval ones were seen in the cells on the 20th day.

Marked dilatation of the intermembranous space of the nuclear envelope (Ashworth et al., 1959; Fujita, 1961), was noticed in the regenerating cells on the 20th day and light cells of control adrenals.

\section{Discussion}

It has been reported previously that incorporation rate of ${ }^{3} \mathrm{H}$-thymidine in regenerating cortical cells were $500 \%, 128 \%$ and $96 \%$ of 
Table 1. Changes of Mitochondria and Endoplasmic Reticulum During the Regeneration of Rat Adrenal Cortice

\begin{tabular}{|c|c|c|c|c|c|c|c|c|}
\hline \multirow{2}{*}{$\begin{array}{c}\text { Days } \\
\text { after } \\
\text { Enuclea- } \\
\text { tion }\end{array}$} & \multicolumn{6}{|c|}{ Mitochondria $* 1$ ) } & \multirow{2}{*}{$\begin{array}{l}\text { Network of } \\
\text { Endoplasmic } \\
\text { Reticulum }\end{array}$} & \multirow{2}{*}{$\begin{array}{c}\text { Plasma } \\
\text { Corticosterone } \\
\text { Level } * 2 \text { ) }\end{array}$} \\
\hline & Shape & $\begin{array}{c}\text { Tubular } \\
\text { Cristae }\end{array}$ & $\begin{array}{c}\text { Division } \\
\text { (Septile Str.) }\end{array}$ & $\begin{array}{l}\text { Micro- } \\
\text { tubulus }\end{array}$ & $\begin{array}{c}\text { Multilami- } \\
\text { nation }\end{array}$ & $\begin{array}{l}\text { Invagi- } \\
\text { nation }\end{array}$ & & \\
\hline $\begin{array}{l}\text { Intact } \\
\text { Control }\end{array}$ & $\begin{array}{l}\text { Round } \\
\text { and } \\
\text { Oval }\end{array}$ & 11.2 & 2.2 & 7.4 & 1.2 & 0 & $\begin{array}{l}\text { Well } \\
\text { Developed }\end{array}$ & 100 \\
\hline 5 & $\begin{array}{l}\text { Round, } \\
\text { Oval and } \\
\text { Elongated }\end{array}$ & 46.4 & 0.2 & 0 & 0 & 0 & $\begin{array}{l}\text { Poorly } \\
\text { Developed }\end{array}$ & 66 \\
\hline 10 & $\begin{array}{l}\text { Round, } \\
\text { Oval and } \\
\text { Elongated }\end{array}$ & 27.8 & 0.2 & 0 & 0.2 & 0 & $\begin{array}{l}\text { Moderately } \\
\text { Developed }\end{array}$ & 86 \\
\hline 20 & Irregular & 7.4 & 1.2 & 0 & 3.2 & 5.2 & $\begin{array}{l}\text { Well } \\
\text { Developed }\end{array}$ & 156 \\
\hline
\end{tabular}

*1) Values indicates the per cent incidence obtained by observing 500 mitochondria. For details, see test.

*2) Data from the report 1 published previously in this Journal. Value of the intact control was taken as 100 .

that of control tissue at the 5th, 10th and 20th day after enucleation, respectively. The results suggested that a rapid proliferation of cortical cells took place at an early stage after enucleation and it was almost completed by the 20th day. The histological autoradiographic results were fairly in agreement with those previous findings. Evident increase of grains at the 5th day indicates acceleration of DNA synthesis and shortening of cell division cycle. Since the level of plasma corticosterone at this time was $66 \%$ of that of control, it is naturally considered that biosynthesis of corticosterone is carried out even in the 5th day during which the cortical cells are rapidly proliferated. Network of smooth-surfaced endoplasmic reticulum was rarely but distinctly observed at the 5 th day, and its development was parallel to the plasma corticosterone level along with the course of regeneration. As is well-known, the development of networking endoplasmic reticulum is a common feature with steroid hormone synthesizing cells, such as corpus luteum and theca interna cells (Fawcett, 1966). Development of networking endoplasmic reticulum in hyperfunctional adrenocortical cells and its retrogression under hypofunctional state have been reported by Yoshimura et al., (1968b). The present study agreed with those findings. It is conceivable that the developed network formation of smooth-surfaced endoplasmic reticulum is a morphological manifestation of stimulated steroid hormone biosynthesis.

The characteristic shape of mitochondria in zona fasciculata cells has been paid attentions by many investigators. Belt and Pease (1956) reported that the mitochondria of adrenal cortex were variable in size; the maximal diameter of the largest mitochondria amounted to about $3 \mu$. It was also reported that the shape of mitochondria was different in each zone of adrenal cortex; rod-shaped mitochondria with tubular cristae are seen in the zona glomerulosa and oval mitochondria with vesicular cristae are usually observed in the zona fasciculata (Sabatini and De Robertis, 1961). Furthermore, changes of the organelles following the stimulative or suppressive factors to adrenal function were pointed out by many investigators (Luft and Hechter, 1957; Zelander, 1959; Sabatini et al., 1962; Yoshimura et al., 1968b; Sekiyama, 1968). Mölbert and Arnesen (1960) reported that in cortical cells of stressed animals and of special strain animals, which 
have a congenital defficiency of lipid droplets in adrenal cortex, mitochondria of zona fasciculata did not show vesicular cristae, but revealed the usual lamellar cristae as seen in mitochondria of other tissues. Later, Sabatini et al., (1962) reported that mitochondria of fasciculata cells in hypophysectomized rat were provided with the straight tubular cristae as similar to those of zona glomerulosa cells, and these cristae were transformed to the vesicular type after ACTH administration. The findings of Kahri (1968) that tubular cristae of cultured adrenocortical cells were reverted to vesicular type under the added ACTH in vitro. $\mathrm{He}$ indicated that the mitochondrial cristae is under the control of $\mathrm{ACTH}$, and may be related to the conversion into the original cell function.

As described before, the statistical examination was employed for comparison of mitochondrial changes in the present study. Since the limited ability of electron microscopic method, the values obtained are not so crucial, but may reflect the quantitative changes to some extent. A correlation between the morphological manifestation of mitochondria and the function of adrenocortical cells were pursued by the regenerating cortical cells after enucleation. Within 5 and 10 days after enucleation, the plasma corticosterone concentration is under the control level, then most of mitochondria were small in size and provided with the cristae of tubular profils. Large mitochondria with vesicular cristae appeared after 20 days, when the plasma corticosterone concentration was over the control. However, some mitochondrial enzyme activity, necessary for the biosynthesis of corticosterone, was retained only a half of control level (Ichii et al., 1968). The fact that the vesicular cristae of some mitochondria were in a few number was compatible with the above-mentioned biochemical data, because the biosynthetic enzymes are localized to the inner membrane of mitochondria (Yago and Ichii, 1969).

It was of interest that so-called division (or septile structure) of mitochondria scarcely took place in proliferating cortical cells 5 and 10 days after enucleation, but numerously 20 days. As indicated in Table 1, division of mitochondria may account for the hyperfunctional state of the cortical cells.

Multilamination of mitochondria resembles to so-called myelin figure which is often encountered in glutar aldehyde fixed materials. Multilamination of adrenocortical mitochondria has been observed by Sekiyama (1968) in glutar aldehyde fixed materials previously, and, in the present study, the same structure was observed in osmic acid fixed materials, too. So, it is conceivable that multilamination is not the artefact but a physiological structure in adrenocortical mitochondria. However, its significance on mitochondrial function is ultimately obscure, because multilamination was observed not only in light cells but also in dark cells of fasciculata and reticularis cells (Yoshimura et al., 1968a), and latter two cells were considered to be in hypofunctional state.

Since the invagination of mitochondria observed at the 20th day after enucleation was analogous to that of hepatic cells in stressed animals (Onoe, 1968), this kind of mitochondrial deformity is not a characteristic change in adrenocortical cells, and might be a secondary one caused by hypercorticism.

\section{References}

Ashworth, C. T., G. J. Race and H. H. Mollenhauer (1959). Am. J. Path. 35, 425. Belt, W. D. and D. C. Pease (1956). J. Biophys. Biochem. Cytol. 2, suppl., 369.

De Robertis, E. D. P. and D. D. Sabatini (1958). Ibid. 4, 667.

Fawcett, D. W. An Atlas of Fine Structure: The Cell, W. B. Saunders Co., Philadelphia and London, p. 176, (1966).

Fujita, H. (1961). Z. Zellforsh. 55, 80.

Giacomelli, F., J. Winter and D. Spiro (1965). J. Cell Biol. 26, 499.

Ichii, S., N. Yago, S. Kobayashi and S. Omata (1968). Endocrinol. Japon. 15, 271.

Kahri, A. I. (1968). J. Cell Biol. 36, 181. 
Lever, J. D. (1956). J. Biophys. Biochem. Cytol. 2, suppl., 313.

Luft, J. H. and O. Hechter (1957). Ibid. 3, 615 .

Millonig, G. Electron Microscopy, 2. Academic Press, New York and London, p. 8, (1962).

Mölbert, E. and K. Arnesen (1960). Beitr. Pathol. Anat. allgem. Pathol. 122, 31.

Nishikawa, M., I. Murone and T. Sato (1963). Endocrinology 72, 197.

Onoe, T. (1968). Tr. Soc. Path. Jap. 57, 3 (In Japanese).

Ross, M. H., G. D. Pappas, J. T. Lanman and J. Lind (1958). J. Biophys. Biochem. Cytol. 4, 659 .

Sabatini, D. D. and E. D. P. De Robertis (1961). Ibid. 9, 105.
Sabatini, D. D., E. D. P. De Robertis and H. B. Bleichner (1962). Endocrinology 70, 390.

Sekiyama, S. (1968). Folia Endocrinol. Japon. 44, 633 (In Japanese).

Yago, N. and S. Ichii (1969). J. Biochem. 65, 215 .

Yoshimura, F., K. Harumiya, N. Suzuki and S. Totsuka (1968a). Endocrinol. Japon. 15, 20.

Yoshimura, F., K. Harumiya, M. Watanabe, T. Omoto and T. Sekiguchi (1968b). Ibid. 15, 145.

Zelander, T. (1959). J. Ultrastructure Res. 2, suppl., 1. 
Fig. 3. Control adrenal cortex is composed of four zones, i.e. zona glomerulosa, intermedia, fasciculata and reticularis. $\times 80$.

Fig. 4. Same as Fig. 3. Autoradiography. Mitosis (M) and incorporation of ${ }^{3} \mathrm{H}$-thymidine ( $\uparrow$ ) are localized at so-called intermediate zone. $\times 800$.

Fig. 5. Five days after enucleation. Hemorrhagic necrosis. (NT) and granulation tissues (G) are observed. Parenchymal cells $(\mathrm{P})$ are proliferating in subcapsular region. $\mathrm{X} 80$.

Fig. 6. Same as Fig. 5. Autoradiography. Remarkable incorporation of ${ }^{3} \mathrm{H}$-thymidine is observed not only in subcapsular parenchymal cells, but also in capsular fibroblasts ( $\uparrow$ ). X800.

Fig. 7. Same as Fig. 5. Autoradiography. Parenchymal cells, neighbored to necrotic tissue (NT), reveal remarkable labeling. $\times 800$.

Fig. 8. Ten days after enucleation. Proliferating cells form cord-like arrangement to some extent. X80.

Fig. 9. Same as Fig. 8. Autoradiography. Cortical cells in subcapsular region show moderate incorporation of ${ }^{3} \mathrm{H}$-thymidine. $\times 800$.

Fig. 10. Twenty days after enucleation. Cortical cells form obvious cord-like arrangement. $\times 80$.

Fig. 11. Same as Fig. 10. Autoradiography. Weakly labeled cells are observed in subcapsular Region ( $\uparrow$ ), although their number is limited. $\mathrm{X} 800$. 


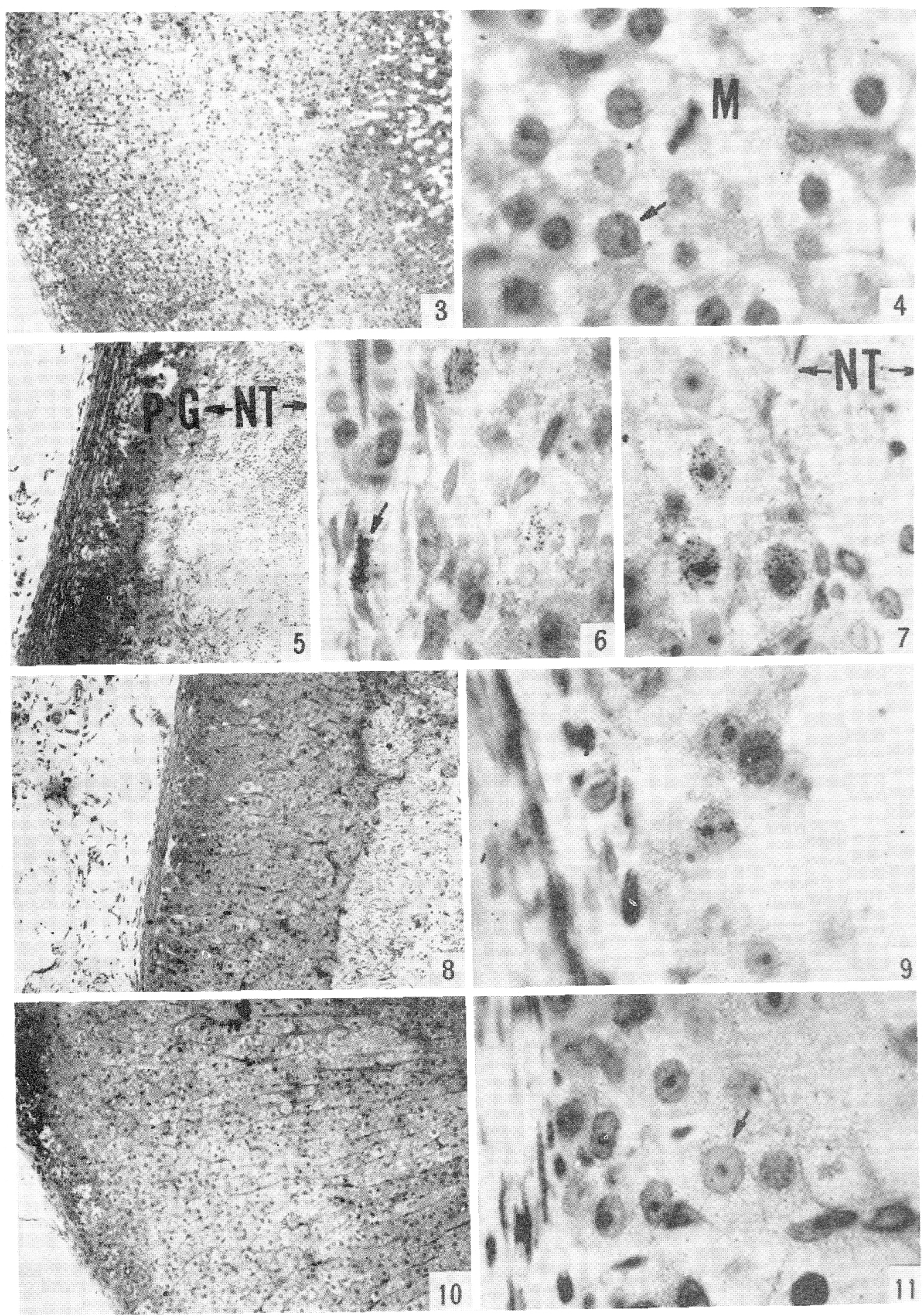


Fig. 12. Zona fasciculata of control adrenal cortex. Mitochondria (Mt) have highly variable size with vesicular cristae. Arrow indicates so-called division (or septile structure) of mitochondria.

$$
\text { Nc-.- Nucleus No - - Nucleolus G -.- Golgi complex }
$$

$\times 9000$

Fig. 13. Multilamination of mitochondria in a dark cell of control adrenal cortex. $\times 50000$.

Fig. 14. Microtubulus in mitochondria of control adrenocortical cell. X62000. 


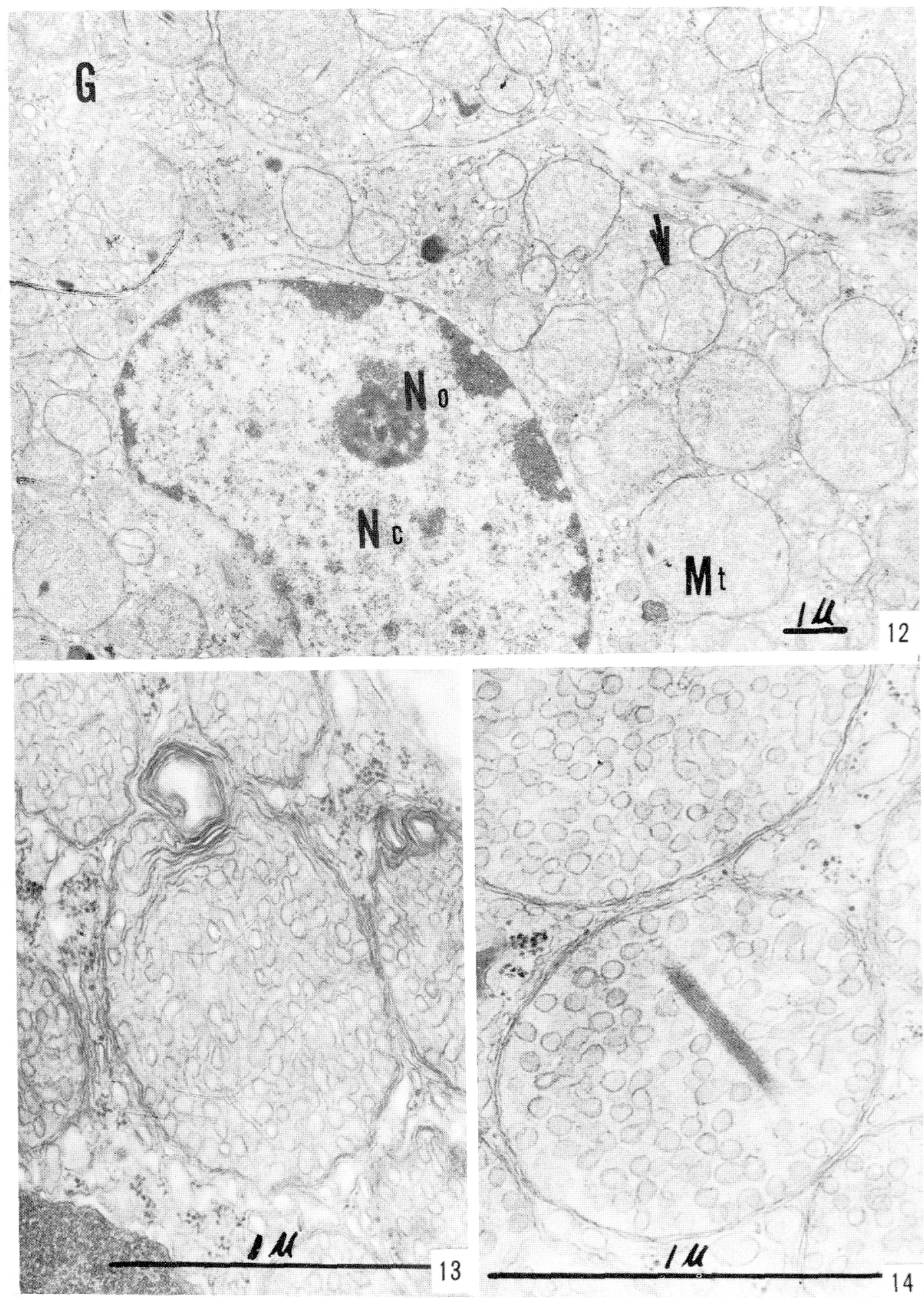


Fig. 15. Five days after enucleation. Most of mitochondria (Mt) are small and round or oval in shape with tubular cristae. Lipid droplets show star-like profiles. Nc - - Nucleus $\times 7500$.

Fig. 16. Five days after enucleation. Elongated mitochondria are frequently encountered. Arrow indicates poorly developed network of smooth surfaced endoplasmic reticulum. X49000. 


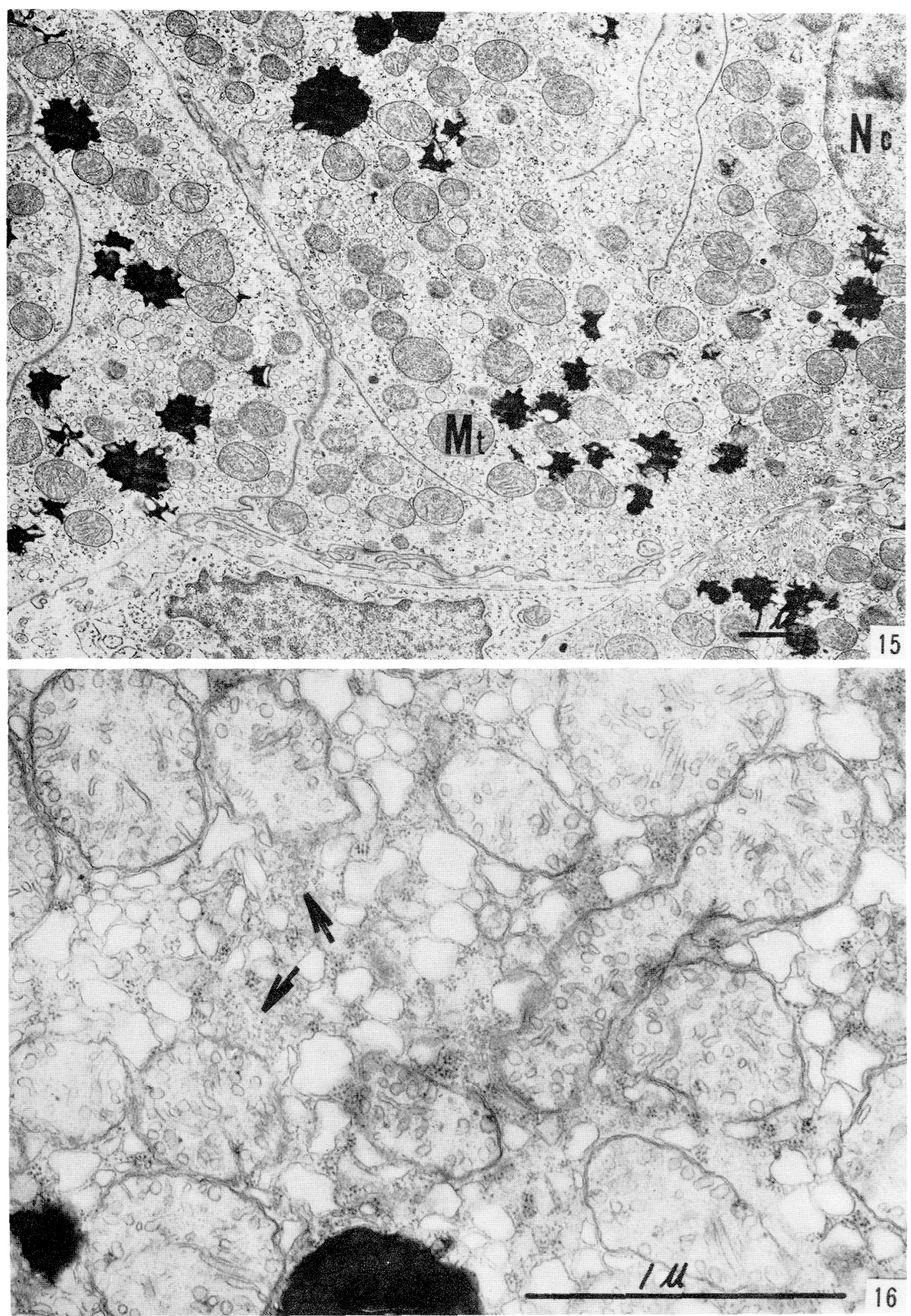


Fig. 17. Five days after enucleation. Network of smooth-surfaced endoplasmic reticulum (NEs) can be observed in some cortical cells. Mt - - Mitochondria. X110000.

Fig. 18. Ten days after enucleation. Many of mitochondria (Mt) contain tubular or tubulo-vesicular cristae. Elongated mitochondria $(\uparrow)$ is still remaining. Lipid droplets show irregular outline.

Nc - - Nucleus. X110000. 


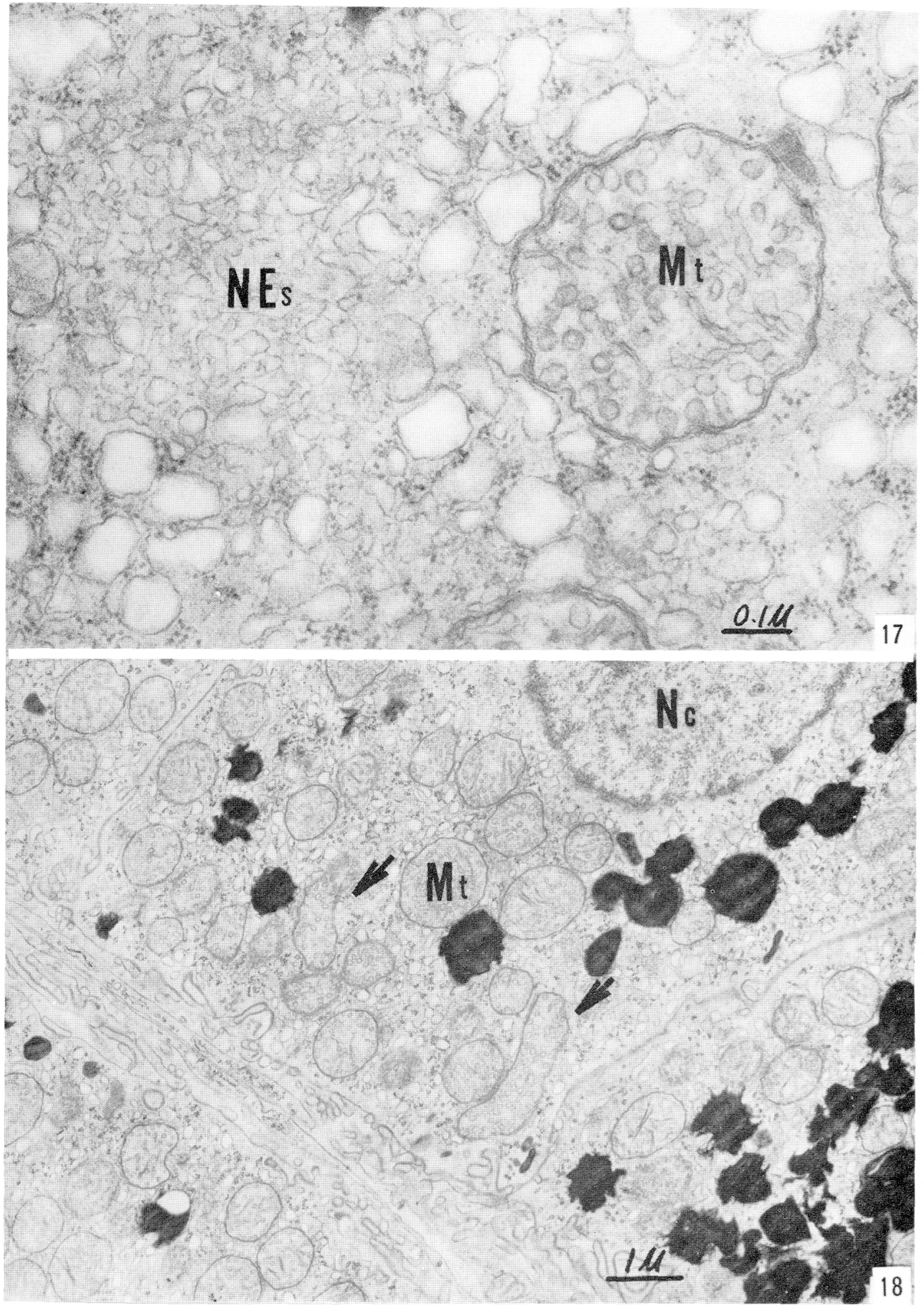


Fig. 19. Twenty days after enucleation. Mitochondria (Mt) are large in size and irregular in shape with vesicular cristae. Multilamination $(\uparrow 1)$ and dilatation of internal space of nuclear envelope $(\uparrow 2)$ are seen.

Nc - - Nucleus

G - - Golgi complex $\mathrm{x} 11000$.

Fig. 20. Twenty days after enucleation. Some mitochondria contain decreased number of vesicular cristae, as compared with those of control. $\times 36000$.

Fig. 21. Twenty days after enucleation. Invagination of mitochondria ( $\uparrow) . \times 11000$. 


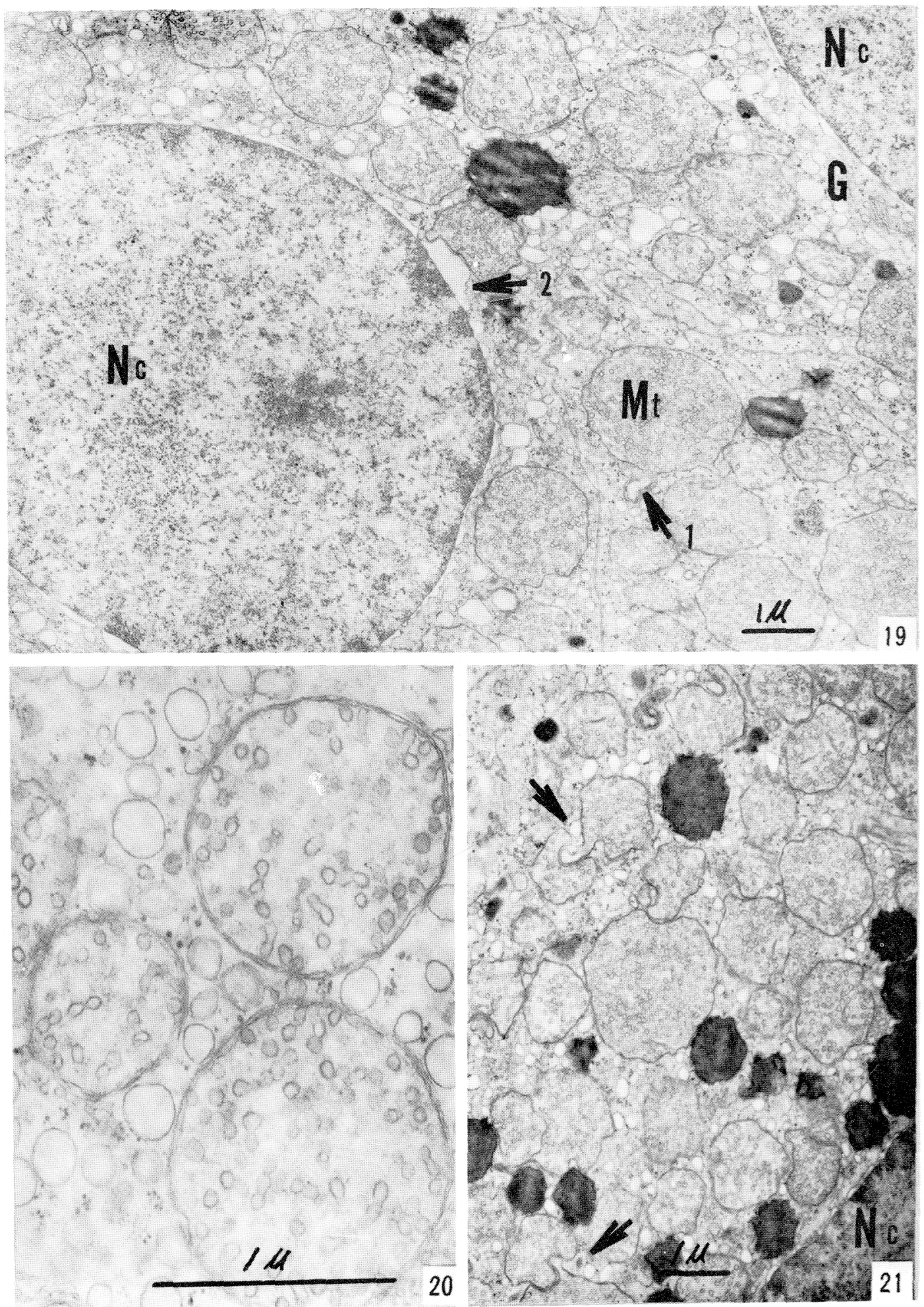

